\title{
Appraisal of the Protection of the Rights and Interests of Electricity Consumers in Nigeria
}

\author{
Festus Okechukwu Ukwueze, Ph.D* \\ Faculty of Law, University of Nigeria, Enugu Campus, Enugu State Nigeria \\ Peace Chiedozie Onubuleze \\ Faculty of Law, University of Nigeria
}

The authors did not have sponsorship for the study

\begin{abstract}
This article analyses the various statutes, regulations that provides for the rights of electricity consumers in Nigeria, the liabilities of the service providers and the redress mechanisms available to the consumers based on the Electric Power Sector Reform Act 2005 and the newly enacted Federal Competition and Consumer Protection Act 2018. The study reveals that the provisions of the law aimed at protecting the rights and interest of electricity consumer in Nigeria are quite adequate but consumers continue to suffer deprivations of their rights owing to inadequate enforcement of the law as well as lack of awareness and apathy on the part of the consumers themselves.
\end{abstract}

Keywords: Electricity, Consumer rights and interests, Consumer protection, Nigeria

DOI: $10.7176 / \mathrm{JLPG} / 92-14$

Publication date: December $31^{\text {st }} 2019$

\section{Introduction}

From the turn of the $21^{\text {st }}$ century, the Federal government of Nigerian embarked on series of reform in the country's electric power sector in a bid to salvage that sector from total collapse and ensure adequate and efficient power supply to the populace. Through appropriate policies and legal instruments, the sector which used to be a public monopoly was unbundled into several partially privatized entities and a regulatory body, the Nigerian Electricity Regulatory Commission (NERC) was established to oversee the functioning of the sector. However, it appears that the much anticipated improvement in power supply and efficiency has not been realised with the result that the Nigerian electricity consumers have been at the receiving end bearing the brunt of inadequate supply and high cost of electricity. In both rural and urban areas consumer complaints are rife. These complaints centre on lack of supply of electricity owing to constant power outage, wrongful billing and disconnection.

In many states, the inhabitants are not happy with the services of the distribution company in charge. For example, in Enugu state, the shoddy services of the Enugu Electricity Distribution Company (EEDC) being the company in charge of the electricity distribution in the State came to a height that it became a subject matter before the session of the Enugu State House of Assembly wherein the House unanimously passed vote of no confidence on the company. ${ }^{1}$ The action became imperative at a time when hundreds of residents occupied the Assembly Complex, insisting that the distribution company must exit the State due to their perceived activities as day-light robbery. ${ }^{2}$ This is too bothersome considering the fact that the whole idea of the privatization of the power sector was to increase efficiency in the system. Ironically, the privatization benefits only reflected successfully in the change of names. ${ }^{3}$ The poor services and the high overestimated charges have continued to the chagrin of consumers.

It is in the light of the level of consumer discontent with the services of the now partially privatised electricity section that this paper examines the rights of the consumers and liabilities of electricity companies the relevant laws with a view to determining the adequacy of the protection. The paper analyses the relevant provisions of the Electric Power Sector Reform Act 2005 and the new Federal Competition and Consumer Protection Act 2018 with a view to identify the rights of consumers and liabilities of the electricity companies to the consumers under these laws.

\footnotetext{
${ }^{1}$ E Uzodinma, 'Law Makers Pass Vote of no Confidence on EEDC' http://dailypost.ng/2017/04/07/happening-now-enugu-lawmakers-passvote-no-confidence-eedc/ accessed 8 April 2019; C Ihuoma, 'Enugu Electricity Distribution Company, Enugu Assembly Fight Over Electricity Bills' [16 April 2017] https://punchng.com/eedc-enugu-assembly-fight-over-electricity-bills/ accessed 8 April 2019. ${ }^{2}$ Ibid.

${ }^{3}$ The change of name from the former National Electric Power Authority (NEPA) to Power Holding Company of (PHCN) and to the latter names it bears today, each reflecting the owners' choice of names. For instance, in Enugu State, it is the Enugu Electricity Distribution Company (EEDC) however, it is called Kaduna State, it is Kaduna Electric et cetra.
} 


\section{Clarification of Concepts}

The concept Consumer has been a subject of diverse and variant definitions with each reflecting the purpose for which it is sort to be defined. General statutes such as the Federal Competition and Consumer Protection Act defines 'consumer' to include any person who purchases or offers to purchase goods otherwise than the purpose of resale but does not include a person who purchases any goods for the purpose of using them in the production or manufacture of any other goods or articles for sale, or to whom a service is rendered. ${ }^{1}$ Going by this general definition, a person who purchases electricity for use in his or her business may not qualify as electricity consumers. However, sector specific statutes define the term in ways that capture the peculiarities of the sector in question. For instance, a consumer has been defined to include to whom and idea is offered. ${ }^{2}$ Thus, the Electric Power Authority Section Reform Act defines 'consumer' as:

... any end-user of electricity who is a customer of a distribution licensee that is not an eligible customer and, for purposes of filing a complaint with the Commission and for any other reason that the Commission may determine, a person who is temporally disconnected or otherwise without service, provided that a person who has applied for, but has yet to receive, service shall also be deemed to be a consumer. ${ }^{3}$

Thus, a electricity subscriber who is temporarily disconnected as well as any person has applied and paid to a distribution company for electricity supply which is not yet provided are deemed to be consumers under the Act. This definition is purposeful for a number of reasons. First, the reference to any end user takes care of situation where a tenant becomes a consumer by virtue of an arrangement between his landlord and an electricity company. Secondly, it captures even 'would be customers' as consumers for the purposes of filing complaints with the Commission or for any other reason including court proceedings, so long as the prospective customer has applied for electricity.

Consumer protection according to Ladan is about the provision of appropriate and effective mechanisms to protect the pecuniary, health, safety and security interest of all legal persons against misleading, fraudulent and harmful business practices including manufacturing, trading, packaging, advertising, distribution and selling of products/goods and services to the ultimate consumers. ${ }^{4}$ Similarly, Monye offers a definition of the concept as the act of safeguarding the interest of the consumer in matters relating to the supply of goods and services, fraudulent and hazardous practices as well as environmental degradation. ${ }^{5}$

The rights of the consumer in Nigeria are routinely violated by the supply of defective products and shoddy services despite the fact that there are existing laws and regulatory bodies established to protect the interest of the consumer. ${ }^{6}$ Majority of the available literature on the Nigerian electricity sector are general criticisms of the poor services of the electricity distribution companies (DisCos) with very few touching on the protection of electricity consumers. Consumer complaints against DisCos in Nigeria are myriad and include non-provision and inadequate supply of electricity for prolonged periods, excessive billing and billing for power not supplied, wrongful disconnection and so on. Many commentators have condemned non-metering of consumers and the consequent practice of estimated billing, which they say is peculiar to Nigeria and not obtainable in other jurisdictions where tax on electricity is based on better tariff methodology instead of the disparaging concept of estimated billings. ${ }^{7}$ Through estimated billing, DisCos impose on consumers, charges for energy they did not consume. It has been observed that in some parts of the country, the power supply situation has worsened since the sector was privatized in November 2013 and has resulted in some stakeholders demanding the revocation of the licenses issued to the operators. ${ }^{8}$ Some have asserted that privatisation has merely turned the electricity sector from public monopoly to a private monopoly by government handing public assets to private operators who have no personal track record in electricity generation and distribution and without a robust regulatory regime intended to protection the rights and interests of consumers of the citizens by controlling the production and price of goods and services to make them affordable and available.

\footnotetext{
${ }^{1}$ Federal Competition and Consumer Protection Act (FCCPA), No 1 of 2018, s 167

${ }^{2}$ O Olugosa et al. 'Recent Developments in Consumer Protection in Nigeria' (Draft paper presented at $49^{\text {th }}$ Annual Nigerian Association of Law Teachers (NALT) Conference, 4.

${ }^{3}$ Electric Power Sector Reform Act (ESPRA), No 6 of 2005, s 99.

${ }^{4}$ MF Ladan: The Limits of Legal Enforcement and Regulatory Frameworks in Consumer Protection Against Counterfeit and Pirated Products: The Nigerian Experience (2008) (2) (1) Review of Nigerian Law and Practice 3, quoted in a O Olugosa et al, 'Recent Developments in Consumer Protection in Nigeria' (Draft Paper Presented at $49^{\text {th }}$ Annual Nigerian Association of Law Teachers (NALT) Conference) 4

${ }^{5}$ FN Monye, Law of Consumer Protection (Ibadan: Spectrum Books, Limited 2003) 20.

${ }^{6}$ AI Yetunde, 'Unlike NEPA, the Distribution Companies Can be Sued for Outrageous Bills' https://www.independent.ng/unlike-nepa-discoscan-sued-outrageous-bills/, accessed 7 April 2019.

${ }^{7}$ I Peters, 'Estimated Electricity Billing System in Nigeria: Exorbitant Charges, A Deficient Economy and Consumer's Right - The Nexus' https://dnllegalandstyle.com/2018/estimated-electricity-billing-system-in-nigeria-exorbitant-charges-a-deficient-economy-and-consumersright-the-nexus/, accessed 17 April 172019.

${ }^{8}$ F Okoromadu, 'Discos And Blame Game In Nigeria's Electricity Sector Leadership Newspaper (Lagos, 11 May 2017) https://leadership.ng/2017/05/11/discos-and-blame-game-in-nigerias-electricity-sector/ accessed 15 November 2019.
} 


\section{Legal Framework for the Protection of Electricity Consumers in Nigeria 3.1 The Electric Power Sector Reform Act, 2005}

The Electric Power Sector Reform Act 2005 (EPSRA) is the principal legislation for the regulation of the electricity sector in Nigeria. The regulatory ambit of the Act covers generation, transmission, distribution and supply of electricity, enforcement of performance standards, consumer rights and obligations, determination of tariff and related matters. ${ }^{1}$ The stated objectives of the Act include to maximise access to electricity services by promoting and facilitating consumer connections to the distribution systems in both rural and urban areas; ensure that an adequate supply of electricity is available to consumers; to ensure that the prices charged by licences are fair to consumers and are sufficient to allow the licensee to finance their activities and to allow for reasonable earnings for efficient operations; ensure the safety, security and reliability and quality of services in the production and delivery of electricity to consumers. ${ }^{2}$ The Act establishes a regulatory body, the Nigerian Electricity Regulatory Commission (NERC) ${ }^{3}$ charged with the responsibility to, among other things, promote competition and private sector participations when and where feasible; establish appropriate consumer rights and obligations regarding the provision and use of electricity services; monitor the operation of the electricity market; and undertake such other activities which are necessary for the better carrying out or giving effect to the objectives of the commission. ${ }^{4}$ The Act specifically charges the Commission in the discharge of its functions, to consult from time to time, and to the extent that the Commission considers appropriate, such persons, groups of persons who may or are likely to be affected by the decisions or orders of the Commission including but not limited to licensees, consumers, etc.. ${ }^{5}$ The provision is a demand puts a call on the Commission to be responsive to the feelings and comments of the consumers and this can be best achieved by going into the field and taking empirical surveys on consumer/suppliers relationship, identifying the problems and making appropriate regulations.

The Commission shall issue written reasons in respect of any decision or orders affecting the existing rights of any person, if a person requests such written reasons and on other decision or orders as the Commission deems necessary. ${ }^{6}$ In other words, a consumer would have access to such documents if he so wishes and the written reason for their decision stated therein. This would help to review the decisions of the Commission by a higher judicial order if need be. This would ease access to justice for consumers who wish to go beyond the dispute resolution forum provided by the Commission.

The Commission shall be led by the principle of fair hearing which include; issuance of notice and opportunity to be represented. ${ }^{7}$ The Act enjoins the Commission, where any question of law arises from an order or decision of the commission, it may suo motu initiate or at the request of any person directly affected by such order, reserve the question for the decision of the higher court ${ }^{8}$ and shall refer matters of technical and professional consideration to person who are qualified and learned in the field..$^{9}$

A critical and commendable provision for consumer protection is provided under part IV of the Act, on licences and tariffs. The Act provides that no person except in accordance with a licence issued pursuant to the Act, shall construct, own or operate or undertake or in any way engage in the business of electricity transmission distribution. ${ }^{10}$ This is to ensure water tight regulation of the sector to avoid indiscriminate exploitation of the market by unlicensed operators to the detriment of the consumers. The Act mandates that every licensee shall comply with the provisions of his licence regulations, codes and other requirements issued by the Commission from time to time ${ }^{11}$ and the Commission shall have the authority to penalise a licensee for violation of his licence terms and conditions or to cancel such licence in accordance with the prevision of the Act. ${ }^{12}$ This is a major instrument of control on DisCos to make them abide by the terms of the license to avoid having their licenses revoked.

Tariffs are regulated to prevent abuse of market powers ${ }^{13}$ and the Commission is required in adopting methodologies for fixing tariffs to consider such tariffs that will allow licences to operate efficiently to recover the full cost of its business activities including a reasonable return on the capital invested in the business. ${ }^{14}$ This provision considers both the interest of the investors in the companies and the consumers and tries to strike a

\footnotetext{
ESPRA, Long title.

2 Ibid, s 32 (1) (b)-(c)

${ }^{3}$ EPSRA 2004 s 31.

${ }^{4}$ Ibid s $32(2)$

${ }^{5}$ Ibid s 32 (3).

${ }^{6}$ Ibid s 46 (2) (3).

${ }^{7}$ EPSRA s $47(2)$

${ }^{8}$ Ibid, s 49.

${ }^{9}$ Ibid s 48 .

${ }^{10}$ Ibid s 62 (1) 6; s 62 (1) (c)

${ }^{11}$ Ibid s 63(1).

${ }^{12}$ Ibid s 62(7)

${ }^{13}$ Ibid s 76 (1) (a).

${ }^{14}$ Ibid s 76 (2).
} 
balance between the need for the investors to prudently recoup their investments while providing adequate services to her customers at moderate and affordable cost. In preparing a tariff methodology, the Commission is also required to consider representation made by licensees, customers, consumer associations and obtain information or advice from persons with expert knowledge relevant in the preparation of the methodology. ${ }^{1}$ The reason for the representation is to enable the Commission factor in the different interest in the sector. The Commission is required to widely publicise any review of the tariff methodology ${ }^{2}$ so as to give consumers notice of same and also afford members of the public, who desire to have full information on how he is billed for the power consumed and have the opportunity to contend the methodology used if aggrieved.

The Act prohibits licensees from recovering or transferring any fine or penalties levied upon them to their customers. ${ }^{3}$ Contravention of this carries stipulated penalties. ${ }^{4}$

Part (VI) of the Act establishes the consumer protection standards and provides that the Commission shall develop in consultation with the licensees, consumer service standards. ${ }^{5}$ pursuance to these standards, the Act under section 96 provides that the Commission may make regulations prescribing all matters which by the Act are required or permitted to be prescribed or which in the opinion of the Commission are necessary or convenient to be prescribed for carrying out or giving effect to the Act. The Commission shall develop these regulations in consultation with the licensees.

\subsection{Federal Competition and Consumer Protection Act, 2018}

The Federal Competition and Consumer Protection Act, 2018 (FCCPA) repealed the Consumer Protection Council Act, 1992 (CPCA) ${ }^{6}$ and established the Federal Competition and Consumer Protection Commission $(\mathrm{FCCPC})^{7}$ and the Federal Competition and Consumer Protection Tribunal (FCCPT). ${ }^{8}$ FCCPA is currently the hub of consumer protection in Nigeria and specifically seeks to protect and promote the interest and welfare of consumers by providing consumers with wider variety of quality products, services and competitive prices. It prohibits restrictive or unfair business practices which prevents, restricts or distort competition or constitute an abuse of a dominant position of market power in Nigeria and contribute to the sustainable development of the Nigerian economy. ${ }^{9}$

FCCPC is charged with powers to initiate broad based policies and review economic activities in Nigeria, identify anti-competitive, anti-consumer protection and restrictive practices which may adversely affect the economic interest of the consumers and make rules and regulations under the Act and any other enactment with regards to competition and protection of the consumers; eliminate anti competitive agreements, misleading, unfair, deceptive or unconscionable marketing, trading and business practices; protect and promote consumer interest, organize or undertake campaigns and other forms of activities capable of promoting increased private and public consumer awareness. Others include to resolve disputes or complaints, issue directives and apply sanctions where necessary; ensure that consumer's interest receive due consideration at appropriate time and provide redress to obnoxious practices or the unscrupulous exploitation of consumers by companies, firms, trade associations or individuals; ensure that all service provides comply with local and international standards of quality and safe service delivery; cause an offending company, firm, trade, association or individual to protect, compensate, provide relief and safeguards to injured consumers or communities from adverse effects of technologies that are inherently harmful, injurious, violent or highly hazardous. ${ }^{10}$

FCCPT has adjudicatory powers to hear appeals or review any decision of the Commission taken in the course of the implementation of the Act, as well as appeals from or review of any decision of the powers sector specific regulatory authorities in respect of competition and consumer protection matters. ${ }^{11}$

Part IX of FCCPA prohibits the abuse a dominant position. Section 70 (2) explains a dominant position in relevant market as where an undertaking enjoys a position of economic strength enabling it to prevent effective competition being maintained on the relevant market and having the power to behave to an appreciable extent

\footnotetext{
${ }^{1}$ Ibid, s $76(7)$ (a) ( b) (8).

${ }^{2}$ Ibid s $76(9)$.

${ }^{3}$ Ibid s 76 (13).

${ }^{4}$ Ibid, s 76 (14). The Distribution Company shall be liable to a fine two times the charge to the licensee's customers or imprisonment of not more than one year or both.

${ }^{5}$ EPSRA, s 80. Other materials to be developed by the Commission includes: Customer complaint handling standards and procedures, Codes of practice for the provision of assistance to special needs customers such as the blind or disabled, the elderly or severely ill, the procedures for dealing with or assisting customers who have difficulty in paying bills, procedures for applying for electricity services, procedures for disconnecting non paying customers or those in breach of other terms and conditions of an applicable tariff or contract and the information to be provided to the customers and the manner of its disseminations.

${ }^{6}$ Cap C25, Laws of the Federation of Nigeria (LFN) 2004

${ }^{7}$ FCCPA s 3.

${ }^{8}$ Ibid s 39.

${ }^{9}$ Ibid s 1 (c) (d) (e).

${ }^{10}$ Ibid s 17 (1) (a) - (z).

${ }^{11}$ Ibid. s. 47
} 
independently of its competitors, customers and ultimately consumers. It is thus, a situation where a growing concern, supplier, service provider is able to act without taking account of the reaction of its customers, consumers or competition. This seems to be the situation in Nigeria's electricity market. There is absence of alternative companies to supply or distribute power. The country has been partitioned with a DisCo taking exclusive charge of each part, a situation which calls for stringent regulation to keep them in the proper track of global best practices in the power sector. Nevertheless, the Act prohibits the abuse of this position ${ }^{1}$ and gives clue as to determine when it occurs which includes but not limited to where they charge excessive price to the detriment of the consumers. ${ }^{2}$

\subsection{Protection under the General Law}

Apart from the protection provided to electricity consumers under the relevant statutes, consumers enjoy some measure of protection under general law of contract and tort. A contract simply put is an agreement giving rise to obligations which are enforced or recognized by the law or an agreement upon sufficient consideration to do or not to do a particular thing. ${ }^{3}$ The legal relation created by the law of contract enables a person to whom money goods, services or some other benefits has been promised to enforce the promise or to obtain a remedy for its breach. $^{4}$

A contract can be express or implied depending on the circumstances giving rise to the relationship. For instance, where a person purchases cables, wires his house and invites any of the field officers of a distribution company to connect to the company's supply, he is deemed to have agreed to the terms which includes:payment of power units consumed, metre maintenance fee etc. These notwithstanding, the Nigerian Electric Regulatory Commission's Connection and Disconnection Procedures for Electricity Services 2007 make provision for express creation of contractual obligation between DisCos and consumers or customers.

Paragraph 3 of the Regulation provides inter alia that whenever a customer desires to obtain electricity supply from a DisCo to premises where there was no connection to the distribution system, the customer shall submit an application for electricity supply in format required by the DisCo and approved by the Commission, provide a declaration of supply requirements completed by an appropriate authority. ${ }^{5}$ The appropriate authority assess and approves the premises for the purposes of the connection of electricity in a format required by the DisCo and approved by the Commission and pay any capital contribution, connection charge and security deposit required by the DisCo and approved by the Commission. The distribution company shall consequently connect the customer's supply address as soon as practicable, but not later than 48 hours after the customer applies for connection in accordance with the Regulations. ${ }^{6}$

From the above provisions, it can be validly be posited that there is existence of conditional contract, ${ }^{7}$ whereby the intending customer is expected to perform some specific acts which would bind the service provider to perform its own part of the arrangement without which the customer can sue for specific performance or damage if any or both. Therefore, the DisCo is bound to connect the customer as much as the customer is bound to fulfil his own part of the bargain.

The idea of tort of negligence is to create liability even in the absence of privity in a contract. That is to say, it covers more people in the chain of liability than the contract law in as much as there exist duty of care, breach of the duty and the consequential damages. ${ }^{8}$ Generally, tortuous liability arises from the breach of a duty primarily fixed by law. This duty is towards persons generally and its breach can be redressed by an action for unliquidated damages. ${ }^{9}$ Negligence is a breach of a legal duty to take care which results in damage which may have not been desired or even contemplated by the person committing the breach to the person to whom the duty is owned. ${ }^{10}$

It is the omission to do something which a reasonable man guided by those considerations which ordinarily regulate the conduct of human affairs would do, or doing something which a reasonable and prudent man would

\footnotetext{
${ }^{1}$ Ibid s $72(1)$

${ }^{2}$ Ibid s (72) (1).

${ }^{3}$ Commentaries on the Laws and Constitution of England (American Bar Association Publishing Library 2009) 222 quoted in EO Ezike, Nigerian Contract Law (Enugu: Chengbo Limited, 2018) 1; see generally, Orient Bank (Nig) Plc v Bilante International Ltd [1997] 8 NWLR (Pt 515) 37, 76; Nwangwu v First Bank of Nigeria Plc [2009] 2 NWLR (Pt. 1125) 203, 227.

${ }^{4}$ IE Sagay, Nigerian Law of Contract Law (2nd edn, Ibadan: Spectrum Books Limited, 200) 1-2.

${ }^{5}$ Appropriate authority means any person or official certified or approved by a Distribution Company to assess and approve premises for the purposes of the connection of electricity; see para 13 of the Regulations for definitions of other key terms as used by the Regulation. ${ }^{6}$ paragraph 2(b) of the Regulation

${ }^{7}$ Conditional contract is such a contract that arise only on the performance or the coming into effect of certain specified event without which the arrangement fails. See also EO Ezike, Nigerian Contract Law (Enugu: Chengbo Limited, 2018) 2.

${ }^{8}$ See generally, Donoghue v Stevenson [1932] AC 562; Grant v Australian Knitting Mills Ltd [1936] AC 85. 101 - 102. Osemobor v Niger Biscuits [1973] 7 CCHCJ. 71 quoted in IP Enemuo, The law of Tort (Enugu: Chenglo Limited 2000$) 1$.

${ }^{9}$ WNH Rogers, 'Winifield \& Folowiez on Torts, 7th edn. (London: Sweet and Maxwell, 2006) 50; quoted in IP Enemuo, 'The law of Tort' (Enugu: Chenglo Limited 2000) 1.

${ }^{10}$ Torts Law Cap 150 Revised Laws of Enugu State 2004, s 217.
} 
not do. ${ }^{1}$ It therefore, means that the DisCos must exercise due diligence and care while connecting or disconnecting the customers considering the risks usually associated with electricity. Also, they must also consider reasonably the public safety while installing its equipments to avoid damage of lives and properties. In $N E P A \vee$ Akpata $^{2}$ the plaintiff sued the defendant for damages he sustained as a result of the high tension electric transmission lines negligently erected by the defendant over and above the properties of the plaintiff which made the buildings uninhabitable. The defendants was found liable by the court of first instance trial, but on appeal to the Court of Appeal, allowing the appeal, the court stated that the plaintiff did not establish negligence or damage to his building or even personal injury.

The decision of the Court of Appeal above construed consequential damage too narrow to mean body injuries or destruction of properties. The plaintiff was able to show loss of income from the property as some tenants could not move into the premises due to the high tension cable over the roof which resulted in loss of income.

The distribution company must also take proper care in the quantity and quality of voltage supplied to the consumers in order not to damage the consumer's appliances and should install equipments to regulate it else, they may be found liable in negligence if compromised. ${ }^{3}$

Electricity is a very dangerous thing being handled by the DisCos, the degree of care involved or required must be proportional to the degree of risk involved as held in North Western Utilities $v$ London Guarantee and Accident Co. Ltd \& Ors. ${ }^{4}$

\section{Rights of Electricity Consumers under the relevant Statutes 4.1 General Consumer Rights under FCCPA}

The Federal Competition on and Consumer Protection Act, provides generally for certain rights of the consumers which must be observed. It provides that when an undertaking agrees to perform any service for or on behalf of a consumer, the consumer has a right to the timely performance and completion of those services, and timely notice of any unavoidable delay in the performance of the services; performance of the services in a manner and quality that reasonable persons are generally entitled to expect; ${ }^{5}$ The Act went further to provide that:

Where an undertaking fails to perform a service to the standards contemplated in subsection (1)

of section 130, the consumer may require the undertaking to remedy any defect in the quality of the services performed or goods supplied or refund the consumer a reasonable portion of the price paid for the services performed having regard to the extent of the failure. ${ }^{6}$

Bearing in mind that every consumer has a right to receive services that comply with any applicable standards set by industry sector regulators. ${ }^{7}$ The situation is not different in the electricity sector.

\subsection{Consumer Rights under Nigerian Electricity Regulations}

Pursuant to the power granted to NERC to make regulations for giving effect to consumer rights in EPSRA, ${ }^{8}$ the Commission made and published the Connection and Disconnection Procedures for Electricity Services Regulations, 2007 and the Customer Service Standards of Performance for Distribution Companies Regulations, 2007 both which of which provide certain rights to consumers. These rights include:

4.2.1 Right to Expeditious and Easy Connection and Right to Freedom from Unjustified Disconnections

The Connection and Disconnection Procedures for Electricity Services Regulation set out the procedure for the connection of a consumer who has applied for the supply electricity. Paragraph 2 (c) of the Regulation seeks to forestall cases where tenants move into new premises formerly occupied by another tenant who is indebted to a DisCo, is required to clear the debt incurred by the former tenant. To avoid unwarranted disconnection of supply to consumers, Paragraph 5 of the regulation provides for the conditions upon which a DisCo can disconnect a customer. Such conditions include reasonable notice of the amount owed and the date of proposed disconnection where disconnection is based on outstanding bills. A DisCo can only disconnect a customer's supply without notice under certain circumstances such where the customer is connected to the network illegally or customer's installation to be dangerous to the health and or integrity of the network and/or the quality of supply to other customers. ${ }^{9}$

In OS Oluwabiyi v Abuja Electricity Distribution Company Plc, ${ }^{10}$ the defendant was held liable for

\footnotetext{
${ }^{1}$ Odinaka \& Anor v Moghalu [1990] 4 NWLR (Pt. 233) 1(SC).

2 [1991] 2 NWLR (Pt 175) 536.

${ }^{3}$ NEPA v Alli [1992] LPELR-1955 (SC).

${ }^{4}$ [1936] 3 All ER 200.

${ }^{5}$ Federal Competition and Consumer Protection Act (FCCPA) 2018, s 130 (1) (a), (b).

${ }^{6}$ Ibid s 131(1).

${ }^{7}$ Ibid.

${ }^{8}$ Electric Power Sector Reform Act 2004, s 96.

${ }^{9}$ Connection and Disconnection Procedures for Electricity Services Regulation, Para 6

${ }^{10}$ HC FCT Abuja, Justice UP Kekemeke, Suit No: FCT/HC/CV/734/17 (26 October 2017).
} 
disconnecting electricity supply to the plaintiff in breach of the provisions of the Regulations.

Paragraphs 7 and 8 provide conditions for refusal of the DisCo to supply electricity to the customer which include where the consumer refuses to provide a form of identification acceptable to the DisCo and/or refuses to pay a security deposit requested by the DisCo or the consumer requests to be disconnected.

Under paragraph 11, any DisCo which disconnects electricity supply to premises in violation of the regulations commit an offence and is liable on conviction to pay the customer penalty calculated on daily basis based on the class of consumer. ${ }^{1}$

4.2.2 Right to Easy and Speedy Repair of Faulty Equipment

It is the duty of the customer to procure the materials required for his electricity connection. ${ }^{2}$ It should be noted however, that materials or equipment once integrated into the electricity system or grid automatically becomes the property of the DisCo irrespective of who bought them. In essence, although the customer or individuals purchased the materials or equipment, the responsibility to repair or replace them when the need arises is not to be borne by the customer but by the DisCo to whom they belong. It is therefore, unlawful for individuals or groups (whether or not working with the connivance a DisCo) to disconnect or otherwise, harass consumers on account of their inability to purchase or repair any transformer, poles or other equipments. ${ }^{3}$ The common practice among the DisCos is to abandon the equipment especially in the case of transformers and ask the consumers to contribute and pay, or even leave it till the consumers whom would be placed in worst condition takes steps usually in form of contributions among the collective consumers within the affected area.

The Standard of Performance Regulation therefore, contains provisions to ensure that the DisCos fulfil their obligation of promptly addressing problems arising from faulty equipment. By paragraph 1' of the Regulation, whenever a customer complains to a DisCo that electricity supply to his premises has gone off, the DisCo shall visit the premises within 24 hours to ascertain the cause of the problem. Where the cause of the problem is the DisCos' fuse, it shall be repaired and power restored within twenty four hours. If it is a minor fault, it must be fixed within twenty four hours; and if any other fault the DisCo must fix same within forty eight hours except where it is objectively impracticable for the fault to be rectified within the period. By paragraph 5 of the Standard of Performance Regulation, a DisCo is to respond to a customer's complains about over voltage or under voltage within twenty four hours of the customer's complaints; while regulation requires that a DisCo shall fix or replace a faulty meter within twenty four hours of the customer's complaint.

4.2.3 Right to Metering and Proper Billing

The greatest means of exploiting electricity consumers in Nigeria is in the area of billing by estimation. ${ }^{4}$ In the past five years, over 80 per cent of complaints received by NERC from consumers had been centred on issues of estimated metering, excessive tariffs with the metering methodology and poor metering infrastructure. ${ }^{5}$ Defaults in payment of electricity bills by consumers occur mainly as protests to perceived exploitation and failure to address complaints made to the DisCos. The problem with estimated billing is that bill invariably does not reflect the exact amount of energy consumed but is based on approximation. ${ }^{6}$ The amount charged sometimes remain constant over time even when electricity is rarely consumed and billing were sometimes discriminatory depending on the location of the consumer, ${ }^{7}$ the bill may merely require consumers to pay a specific monthly amount which was not dependent on the units of electricity supplied, consumed or the size of the building for which the bill was generated.

Among all the classes of consumers, the bills of those on estimated tends to be higher compared to that of their counterparts whose consumption are read and metered. ${ }^{8}$ Estimated billing gives room to cheatings, manoeuvring and foul plays. ${ }^{9}$ To curb the high propensity for cheating inherent under the estimated billing arrangement, NERC made the Methodology for Estimated Billing Regulation 2012 which provides a

\footnotetext{
${ }^{1}$ The penalties are (a) Residential buildings, 1000 per day; Commercial consumers, $\$ 1,500$ per day; Industrial consumers, $\$ 2000$ per day and Special consumers, 2000 per day.

${ }^{2}$ Electric Power Sector Customer Service Standards of Performance for Distribution Companies 2007, para 3.

${ }^{3}$ ML Agama, 'Highlights of Consumer Rights under the Nigerian Electricity Supply Industry' [2016] (3) (3) Capital Territory Law Review 25

${ }^{4}$ EO Adegboruwa, 'The Challenges of Consumer Rights in Nigeria: a Case Study in the Telecoms and Power Sector' (The Role of Lawyer in the Protection of Consumer Rights in Nigeria: Lessons from the Telecoms and Power Sector: the theme in Lawyers and National Development, $55^{\text {th }}$ Annual Nigerian Bar Association Conference, International Conference Centre, Abuja, 21 August - 28th August 2015).

${ }^{5}$ C Okafor, 'Metering Accounts for 80\% of Consumer Complaints' Thisday News (Lagos, 29 October 2013) 22

${ }^{6}$ SM Abubakar, 'Design and Construction of a Computer Based Power Billing System' [2009] (39) (34) Published Dissertation, Federal University of Technology, Minna, Niger State, Nigeria. Amadu Bello Univeristy Journal of Technology 13.

${ }^{7}$ CC Ofonyelu and RE Eguabor, 'Metered And Unmetered Billing: How Asymmetric Are The PHCN Bills?' [2014] (1) (5) Journal of Social Economics Research 98 .

${ }^{8} \mathrm{~S}$ Amadi, 'NERC Threatens Distribution Firms on Prepaid Meters' <http://www.nigeriancurrent.com/business-news/item/3531-nercthreatens-distribution-firms-onprepaid-meters.html $>$ accessed 23 August 2019.

${ }^{9} \mathrm{O}$ Ogun,. and CC Ofonyelu, 'Asymmetric Information Problems in the Nigerian Banking Industry: Any Scope for Institutional Reforms' (Paper Presented at the 54th Annual Conference of the Nigerian Economic Society, between September 17-19, at Sheraton Hotal and Towers, Abuja 2013) quoted in CC Ofonyelu and RE Eguabor, Metered And Unmetered Billing: How Asymmetric Are The PHCN Bills? [2014] (1) (5) Journal of Social Economics Research 98.
} 
standardized method to be employed by DisCos in estimating a customer's power usage and bills accruing thereby. Although, the details of the methodology is very technical and beyond the comprehension of an average electricity consumer, the value for the regulation lies in the fact that it provides an objective parameter for assessing the propriety of bills estimates by DisCos. A customer therefore has a basis upon which his actual bill can be determined if he is overbilled.

The most effective way of addressing the exploitation of consumers under the guise of estimated bills remains metering of consumers. Unfortunately, the Commission appears not to have done enough in this regards as against the arrangement when the privatisation came into force. ${ }^{1}$ In 2016 , due to the slow pace of customer metering by the DisCo as well as high level of complaints received from customers and the dissatisfaction with the estimated billing practice, NERC mandated the DisCos to commence implementation of the Credited Advance Payment for Metering Implementation (CAPMI). ${ }^{2}$ To ensure strict compliance to this, under the electricity tariff regime, a customer who has made payment under the CAPMI scheme but was yet to be metered within the allowable 60 days would no longer be billed by the DisCo, and the DisCo will not disconnect him. Nevertheless, NERC has made other successive plans to get the customers metered. ${ }^{3}$ An unmetered customer who is disputing his estimated bill would not be expected to pay such a bill during the dispute resolution process. $^{4}$

\subsubsection{Right to Electricity Service and Supply in Safe and Reliable Manner}

This presupposes that electricity supply and service must be provided in such a manner as not to be injurious or a threat to life and property of consumers. That is to say, actions such as the installation of electricity equipments within and around premises must be conducted bearing in mind the safety of the consumer and the neighbourhood. ${ }^{5}$

\section{Enforcement of Electricity Consumers' Rights}

Enforcement of the rights of electricity consumers may through criminal or civil process. Where the breach in question amounts to a crime under an applicable statute, criminal prosecution can follow. Apart from the specific offences created under ESPRA and FCCPA, under section 304 of the Criminal Code, every person who has in his or her charge or under his control anything, whether living or inanimate, and whether moving or statutory, of such nature that, in the absence of care or precaution in its use or management, the life, safety, health of any person may be endangered has a duty to use reasonable care and take reasonable precautions to avoid such danger; and is held to have caused any consequences which result to the life or health of any person by reason of any omission to perform that duty.

Where the violation of the rights of an electricity consumer involves a breach of contractual or tortious duty, enforcement under civil action can follow. From statistics released by Nigeria Electricity Management Service Agency (NEMSA), in 190 people were victims of 146 electrical accidents in 2017; 113 of these died in 95 accidents while 77 others sustained injuries in another 51 accidents ${ }^{6}$ This statistics covers both staff, home electricity accidents and accidents as a result of negligent installations. The DisCos have always denied negligence on their part and claims acts of the gods (force majure). The court has however, rejected this defence.

\footnotetext{
${ }^{1}$ In November 2013, when the Federal Government privatised the power sector, the country's 11 electricity distribution companies also called DisCos were mandated to bridge metering gap hovering around 4.92 million meters within three years. But only 201,756 meters have been supplied as of 2017 according to industry regulator; Nigerian Electricity Regulatory Commission (NERC). In that arrangement, Nigerians were to be metered freely according the vision under the privatisation arrangement. Available at https:/guardian.ng/businessservices/why-fgs-new-metering-policy-will-create-more-problems-in-power-sector/

2 B Udo, 'NERC Gives Electricity Distribution Companies 120 Days to Engage New Meter Providers' [2018] $<$ https://nerc.ng/index.php/media-library/press-rleases/161-nerc-new-metering-scheme-ckicks-off-today-orders-DisCo-to-supply-previouslypaid-for-by-customers? source=post $>$ accessed 18 August 2019.

${ }^{3}$ Electricity consumers in Nigeria, especially those, who are yet to be metered, will from May first pay $¥ 36,991.50$ or $¥ 67,055.85$ to purchase a single or three phase meter under a newly introduced Meter Asset Providers (MAPs) of the Federal Government. The payment is expected to be a one-off, covering cost and installation of the asset.

MAPs, which came into effect on April, 2018 brought in a set of operators in the power sector to eliminate estimated billing, attract private investment into the provision of metering services, and close the metering gap through accelerated meter roll-out but at the expense of the consumer; Meter Asset Provider (MAP): (MAP) Regulations (No. NERC-R -112) - released on 8th March, 2018 made pursuant to NERC's power to make regulations donated by Section 96 (2) of the Electric Power Sector Reform Act, (ESPRA) 2005. This totally takes the cost of the meter away from the DisCos and placed same on the consumers. This is done through the instrumentality of the Meter Asset Providers, who have been licensed, in conjunction with the DisCos, to supply meters to the premises of customers who request for same and then charge fees of the meter asset in addition to the electricity tariff for a period of 10 years. It is through the meter fees that the MAPs recover their investment and profit in providing the meter, available at https:/guardian.ng/business-services/why-fgs-new-metering-policy-will-createmore-problems-in-power-sector/

${ }^{4}$ NT Makanjuola etal, 'Investigating the Problems of Prepaid Metering Systems in Nigeria'[2015] (16) (2) The Pacific Journal of Science and Technology 22

${ }^{5}$ See Alli v NEPA [1990] LPELR-SC-12/1990; [1992] NWLR (Pt 259) 279.

6 SS Echewofun, 'Electricity: NEMSA Report 133 Death: 77 Injuries in 146 Accident in $2017 \quad[9$ January 2018 ]

$<$ http//www.Dailytrust.com.ng-electricity-nemsa-report-113-death-77-injuries-in-146-accident-in-2017.html> accessed 29 august 2019.
} 
In v Alli $v$ NEPA \& Ors ${ }^{1}$ the defendants sought to deny liability and produced evidence to buttress their claims to have exercised reasonable care and that what had happened was a force majure. The court rejected the defence and relied on the doctrine of res ipsa loquitor to hold them liable in tort of negligence and ordered payment of damage to the plaintiff. ${ }^{2}$

Unjustified disconnection of a consumer is a breach of contract of service and contravention of the law for which the consumer can recover damages for the breach. ${ }^{3}$ But where the customer's installation does not conform to stipulated standards, and a plaintiff is unable to prove that the condition precedent for connection was not met or that there is a contractual relationship between him or her and a DisCo, the plaintiff may not be able to recover damages where he or she suffers loss or damage in consequence of use of electricity ${ }^{4}$

Apart from enforcement through the courts, relevant statutes have empowered the relevant agencies to handle consumer complaints and resolve disputes between consumers and DisCos. The Customer Complaints Handling Standards and Procedures Regulations mandatorily require DisCos to establish Customer Complaint Unit (CCU) to handle customers' complaints expeditiously. ${ }^{5}$ Paragraphs 8 and 9 of the Regulation clearly set out the procedure to be followed by consumers file complaints or seek redress from DisCos which is intended to ensure speedy disposal of complaints. A customer is first to file a complaint with CCU and where he or she is dissatisfied with the pace or outcome of the complaints resolution procedure through CCU can refer the complaint to the Forum, a body created under paragraph 4 of the Regulation to hear and resolve customers' complaints referred to it CCUs in the operational areas of every DisCo. Such complaints can further be escalated to NERC, if the customer is dissatisfied with the handling of the complaint by, or the decision of, the Forum. ${ }^{6}$ The dispute resolution process under the Regulation does not preclude the customer from exercising any other right or privilege including approaching the appropriate regular court for redress. It is submitted that this is the essence of paragragh 13 of the Regulation which provides that nothing in the regulation shall affect the rights and privileges of the customer under any other law.

Under the FCCPA, one of the functions of FCCPC is to "resolve disputes or complaints, issue directives and apply sanctions where necessary. ${ }^{7}$ It is also empowered to cause offending company, firm, and trade to protect, compensate, and provide relief to injured consumers or communities from adverse effects of technologies that are inherently harmful, injurious, violent or hazardous. ${ }^{8}$ The powers of the tribunal extend beyond appeals from FCCPC to appeals from the decisions of other regulatory authorities such as NERC, the Nigeria Communication Commission (NCC), the Standard Organisation of Nigeria (SON) and other regulatory agencies. ${ }^{9}$ However, all appeals or request for review of the exercise of the power of other agencies must first be heard and determined by the Commission before such appeals can go to the tribunal. ${ }^{10}$

This superior status of FCCPC is evident in the provisions sections 104 and 105 of FCCPA which clothed FCCPA with supremacy over all other laws in matters relating to consumer protection and imbue FCCPC with elements of superiority over sector specific agencies in such matters. In essence, where an individual, firm, company, trade union is aggrieved by the contravention of any provision of the enabling statute of a regulatory agency on a matter concerning consumer protection, the starting point is dispute resolution process established by the agency of its enabling statute. If after exhausting the procedure, the person or body remains unsatisfied, an appeal can be brought against the decision of that other agency to FCCPC and subsequently, if need be to the tribunal. The appellate jurisdiction of the FCCPC over other sector specific regulatory agencies is problematic ${ }^{11}$ and may lead to conflict with the exclusive jurisdiction of the Federal High Court as will be shown anon.

An order, ruling, award or judgment of FCCPT in binding on the parties before it and can be registered with the Federal High Court for the purpose of enforcement only. ${ }^{12}$ However, any party dissatisfied with the ruling, award or judgment of the Tribunal can appeal to the Court of Appeal. ${ }^{13}$ A closer look at the sections 54 and 55 implies that the Tribunal has co-ordinate jurisdiction with the Federal High Court on matter relating to consumer protection, with recourse to the Federal High Court for registration of its ruling, award or judgment for the

\footnotetext{
${ }^{1}[1992]$ LPELR-1955 (SC).

${ }^{2}$ See also the cases of Onah v NEPA [1997] LPELR-1959 (SC); NEPA v Malam Muhammad Auwal [2010] LPELR-4577 (CA).

${ }^{3}$ See Oluwabiyi v. Abuja Electricity Distributon Company Plc, HC FCT Abuja, Justice UP Kekemeke, Suit NO: FCT/HC/CV/734/17 (26 October 2017); see section 96 of EPSRA. It provides that any person who contravenes the provisions of the act or any regulation thereto commits an offence and it is liable on conviction, where no specific penalty is prescribed, as a first offender, to a fine of not exceeding one hundred thousand naira or to imprisonment for a period not exceeding one year or both.

${ }^{4}$ Ehimare Ehimen v Benin Electricity Distribution Company Plc [2016] LPELR-40814(CA).

${ }^{5}$ Nigerian Electricity Regulation Commission Customer Handling Standards and Procedures, para 3

${ }^{6}$ Ibid para 3 (9); see also para 7 (4).

${ }^{7}$ FCCPA, s $17(\mathrm{~h})$.

${ }^{8}$ FCCPA, s $17(\mathrm{z})$

${ }^{9}$ Ibid s 47 (1) (b).

${ }^{10}$ Ibid, s $47(2)$

${ }^{11}$ FO Ukwueze, 'Synoptic Review of the Federal Competition and Consumer Protection Act 2018' [2019] Barrister Magazine 88.

${ }^{12}$ Ibid s 54

${ }^{13}$ Ibid s 55(2).
} 
purposes of enforcement only.

Since section 164 (2) of FCCPA permits an aggrieved consumer to directly approach a court with appropriate jurisdiction to seek redress, it can be safely assumed that appeals from other regulatory agencies to FCCPC and from FCCPC to tribunal, should be a matter of discretion. A more worrisome concern is the possible conflict between the appellate jurisdiction conferred on the FCCPC and the tribunal with the exclusive jurisdiction conferred on the Federal High Court by section 251(r) of the Constitution of the Federal Republic of Nigeria 1999 (as amended) in relation to 'any action or proceeding for a declaration or injunction affecting the validity of any executive or administrative action or decision by the Federal Government or any of its agencies.' FCCPC and other regulatory agencies being agencies of the Federal Government, it could be argued that the jurisdiction the proposed Act seeks to confer on the tribunal to review decisions of these bodies is in conflict with the aforesaid exclusive jurisdiction of the Federal High Court.

\section{Conclusion}

From the foregoing discussion, it can be concluded that the relevant provisions of EPSRA and its subsidiary legislation and those of FCCPA highlighted above make fairly adequate provision for the protection of the rights and interests of electricity consumers. Although FCCPA is the principal legislation for the protection of consumers rights generally and claim supremacy over all other laws in matters of consumer protection, its provisions are yet to be fully implemented or subjected to judicial interpretation. EPSRA with its subsidiary legislation are specific to the electricity sector and makes far reaching provisions for the protection and enforcement of rights of electricity consumers, the problems that consumers face in that sector are largely due to lack of strict enforcement of the law. Ignorance and apathy on the part of consumers are factors that contribute to the problems of the consumers in Nigeria generally and not only in the electric sector. Increased consumer education seriously needed at this time to make electricity consumers aware of their rights under the law and how to enforce these rights. Both NERC and FCCPC should accord priority to consumer education. They engage and collaborate with voluntary consumer associations to educate Nigerian consumers on their rights generally and particularly their rights as electricity consumer. Information is key an informed consumer is an active consumer.

References

Adegboruwa, E O 'The Challenges of Consumer Rights in Nigeria: a Case Study in the Telecoms and Power Sector' (The Role of Lawyer in the Protection of Consumer Rights in Nigeria: Lessons from the Telecoms and Power Sector: the theme in Lawyers and National Development, $55^{\text {th }}$ Annual Nigerian Bar Association Conference, International Conference Centre, Abuja, 21 August - 28th August 2015).

Adzenge, S, 'Electricity in Nigeria: a Need to End a Natural Monopoly' [2012] Journal of Nigeria Institute of Advanced Legal Studies 175.

Agama, ML, 'Highlights of Consumer Rights under the Nigerian Electricity Supply Industry' [2016] (3) (3) Capital Territory Law Review 25.

Amadi, S, 'The Rule of Law Approach to Regulating of Electricity Supply in Nigeria [2017] (8) (2) Afe Babalola University: Journal of Sustainable Development Law \& Policy 28;

'NERC Threatens Distribution Firms on Prepaid Meters' <http://www.nigeriancurrent.com/businessnews/item/3531-nerc-threatens-distribution-firms-onprepaid-meters.html > accessed 23 August 2019.

Anod, ST 'NERC and Nigerian's Energy Needs' (2018) <http://www.the tidenewsonline.com/2018/10/31/nercand-nigerias-energy-needs $>$ accessed 7 April 2019;

Echewofun, SS, 'Electricity: NEMSA Report 133 Death: 77 Injuries in 146 Accident in 2017 [9 January 2018] $\mathrm{http} / / \mathrm{www}$. Dailytrust.com.ng-electricity-nemsa-report-113-death-77-injuries-in-146-accident-in-2017.html, accessed 29 august 2019.

Enemuo, IP, The Law of Tort (Enugu: Chenglo Limited 2000)

Ezike, EO, Nigerian Contract Law (Enugu: Chengbo Limited, 2018).

Ihuoma, C 'Enugu Electricity Distribution Company, Enugu Assembly Fight Over Electricity Bills' [16 April 2017] https://punchng.com/eedc-enugu-assembly-fight-over-electricity-bills/, accessed 8 November 2019.

Ladan, MF, The Limits of Legal Enforcement and Regulatory Frameworks in Consumer Protection Against Counterfeit and Pirated Products: The Nigerian Experience (2008) (2) (1) Review of Nigerian Law Practice 3

Makanjuola, NT et al, 'Investigating the Problems of Prepaid Metering Systems in Nigeria'[2015] (16) (2) The Pacific Journal of Science and Technology 22.

Monye, FN, Law of Consumer Protection (Ibadan: Spectrum Books, Limited 2003)

Ofonyelu, CC and Eguabor, RE 'Metered And Unmetered Billing: How Asymmetric Are The PHCN Bills?' [2014] (1) (5) Journal of Social Economics Research 98.

Ofonyelu, CC and Eguabor, RE, 'Metered and Unmetered Billing: How Asymmetric are the PHCN Bills? [2014] 
(1) (5) Journal of Social Economics Research 98.

Ogun,. O and Ofonyelu, CC, 'Asymmetric Information Problems in the Nigerian Banking Industry: Any Scope for Institutional Reforms' (Paper Presented at the 54th Annual Conference of the Nigerian Economic Society, between September 17-19, at Sheraton Hotel and Towers, Abuja 2013)

Okafor, C, 'Metering Accounts for 80\% of Consumer Complaints' Thisday News (Lagos, 29 October 2013) 22

Okoromadu, F, 'Discos And Blame Game In Nigeria's Electricity Sector Leadership Newspaper (Lagos, 11 May 2017) https://leadership.ng/2017/05/11/discos-and-blame-game-in-nigerias-electricity-sector/, accessed 15 November 2019.

Olugosa, O et al, 'Recent Developments in Consumer Protection in Nigeria' (Draft Paper Presented at $49^{\text {th }}$ Annual Nigerian Association of Law Teachers (NALT) Conference) 4.

Peters, I, 'Estimated Electricity Billing System in Nigeria: Exorbitant Charges, A Deficient Economy and Consumer's Right - The Nexus' < https://dnllegalandstyle.com/2018/estimated-electricity-billing-system-innigeria-exorbitant-charges-a-deficient-economy-and-consumers-right-the-nexus/> accessed 17 April 17 2019.

Rogers, WNH, 'Winifield \& Folowiez on Torts, 7th edn (London: Sweet and Maxwell, 2006)

Sagay, IE, Nigerian Law of Contract Law (2nd edn, Ibadan: Spectrum Books Limited, 200)

Udo, B, 'NERC Gives Electricity Distribution Companies 120 Days to Engage New Meter Providers' [2018] $<$ https://nerc.ng/index.php/media-library/press-rleases/161-nerc-new-metering-scheme-ckicks-off-todayorders-DisCo-to-supply-previously-paid-for-by-customers?source=post $>$ accessed 18 August 2019.

Ukwueze, F O 'Synoptic Review of the Federal Competition and Consumer Protection Act 2018' [2019] Barrister Magazine 88.

Uzodinma, E, 'Law Makers Pass Vote of no Confidence on EEDC' http://dailypost.ng/2017/04/07/happeningnow-enugu-lawmakers-pass-vote-no-confidence-eedc/ accessed 8 November2019

Yetunde, AI, 'Unlike NEPA, the Distribution Companies Can be Sued for Outrageous Bills' $<$ https://www.independent.ng/unlike-nepa-discos-can-sued-outrageous-bills/> accessed 7 April 2019. 